\title{
Recent warming in a high mountain lake (Laguna Cimera, Central Spain) inferred by means of fossil chironomids
}

\author{
Ignacio GRANADOS* and Manuel TORO \\ Laboratorio de Limnología Dpto de Ecología, Universidad Autónoma de Madrid, Campus Cantoblanco, 28049 Madrid, Spain \\ *e-mail corresponding author: ignacio.granados@uam.es
}

\begin{abstract}

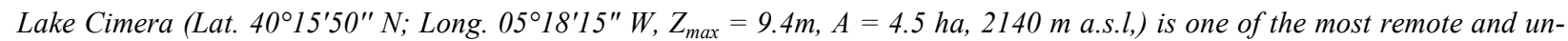
polluted high mountain lakes on the Sierra de Gredos (Central Spain). Intrannual and interannual variability in maximum water temperature and winter oxygen depletion can be related to climate variability (mainly air temperature), through controlling ice cover length. The extent of the oxygen depletion during ice cover period, which is related to this ice cover length, is a key factor controlling the relative abundance of chironomid (Diptera: Insecta) taxa, especially the low oxygen content adapted Chironomus $s p$. In this way, we have found a high negative correlation between the relative abundance of Chironomus head capsules in the sediment and the reconstructed air temperature in the last 200 years $(n=20, r=-0.75, p<0.001)$. The interpretation of such relationship throughout the fossil chironomid assemblage points to a recent warming (since ca mid 1980s) in Lake Cimera. The ecological interpretation of other taxa also supports this view. When applying to fossil chironomids of Lake Cimera the transfer functions developed to reconstruct summer past temperatures in the Alps, it is also well correlated with reconstructed air temperatures $(n=20, r=0.45, p$ $<0.01$ ), especially when only the most accurate dating levels (top of the core, ca 75 years) are taken into account $(n=13, r=0.75, p$ $<0.01)$. However, 1) the linear regressions of both models show significantly different slopes, and 2) chironomid reconstruction underestimates in ca. $3{ }^{\circ} \mathrm{C}$ air reconstruction. The later is probably because the fossil chironomid model has been developed for a different geographical region. Nevertheless, both models provide an independent line of evidence of a recent warming (since ca mid 1980s) in Lake Cimera. Our data also supports the use of chironomids head capsules as an effective tool to infer past temperatures.
\end{abstract}

Key words: high mountain lake, environmental change, temperature reconstruction, chironomids, palaeolimnology, Spain

\section{INTRODUCTION}

In the Sierra de Gredos (Sistema Central, Central Spain) there are more than 20 glacial lakes. Lake Cimera is one of the most remote and best preserved of them (Toro \& Granados 2000). It was included in two EU founded projects, AL:PE2 (Remote Mountain Lakes as Indicators of Air Pollution and Climate Change) and MOLAR (Measuring and Modelling the Dynamic Response of Remote Mountain Lake Ecosystems to Environmental Change), because of its hydrochemical characteristics and its location remote from the main sources of atmospheric pollutants production in Europe (Toro \& Granados 2000). The MOLAR project deals with measuring and modelling the response of remote mountain lakes to environmental change, especially to acid deposition, pollutants influx and climatic variability. In this project, it was included as a secondary site, a control for other lakes as a result of its relatively pristine state. For this reason, not all analyses and experiments carried out at other MOLAR lakes were performed in Cimera. It has been shown that mountain lake ecosystems are sensitive indicators of environmental changes as a result of their hydrochemical characteristics, their relatively low diversity (although some taxonomic groups as diatoms could show relatively high diversity) and their simple food webs (Wathne et al. 1995; McDonald et al. 1996; Toro \& Granados 2000). The main results of analyses from Lake Cimera in the AL:PE2 project have been published elsewhere (Wathne \& Johannessen 1995; Camarero et al. 1995). Since Lake Cimera was one of the least polluted lakes within AL:PE2 project, without symptoms of acidification or high influxes of atmospheric pollutants, it is possible to consider the response to climatic variability at different timescales. Interannual variability is maximal in small lakes like Cimera because of water renewal (Smol et al. 1991). In addition, long-term changes can be detected by means of fossil chironomid assemblages in the sediment record of the lake. The use of this family of Diptera (Insecta) as a paleolimnological tool has been reviewed elsewhere (Walker 1987, 1995). Brooks (1996) provides several reasons why chironomids are useful indicators of environmental changes. However a controversy about the use of chironomids as a powerful tool to infer paleotemperatures has arisen in the scientific literature in recent years (Warner \& Hann 1987; Walker \& Mathewes 1987; Warwick 1989; Walker \& Mathewes 1989; Hann et al. 1992; Walker et al. 1992). Here we present the results concerning intrannual and interannual variability in selected physicochemical water column characteristics, and we also present the recent history (last 200 years) of the lake ecosystem inferred by means of fossil chironomid head capsules. We have tried to use fine-scale temporal resolution, as is recommended by Smol et al. (1991) for these systems. 


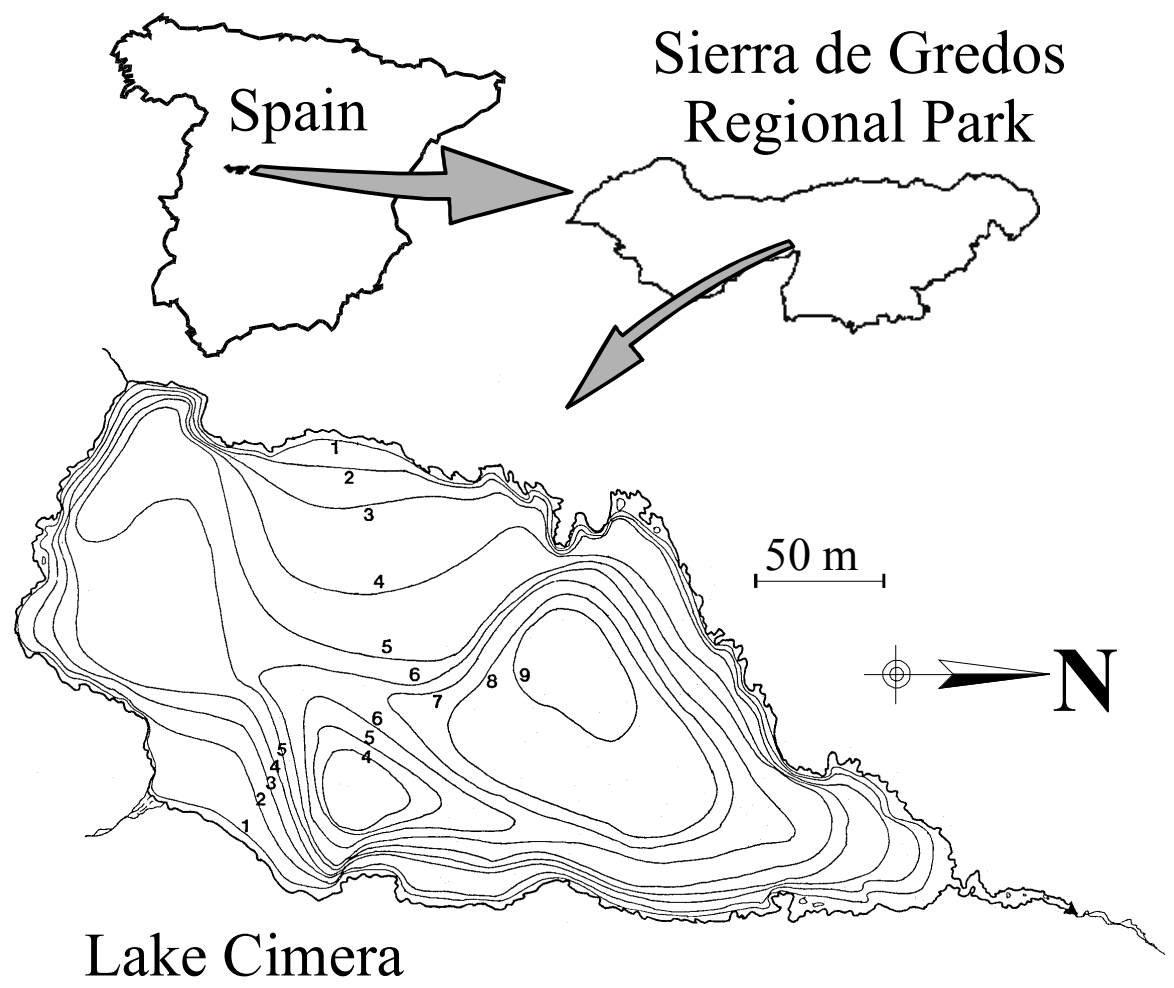

Fig. 1. Lake Cimera location and bathymetric map.

\section{STUDY SITE}

Lake Cimera $\left(40^{\circ} 15^{\prime} 50^{\prime \prime} \mathrm{N}, 5^{\circ} 18^{\prime} 15^{\prime \prime} \mathrm{W}\right)$ is located in the northern slope of the Central Massif of the Sierra de Gredos (Sistema Central, Central Spain, figure 1). It is the highest lake of a series of 5 shallow lakes (max. depth less than $10 \mathrm{~m}$ ) in a small valley glaciated during the Pleistocene. The watershed ranges from $2140 \mathrm{~m}$ a.s.l., at the level of Lake Cimera, to $2568 \mathrm{~m}$ a.s.1. in the highest point. It is a small granite catchment $\left(0.85 \mathrm{~km}^{2}\right)$ composed largely of exposed rock, i.e. mostly without developed soils and only with small grasslands of Nardus stricta and psicroxerophytic meadows. The lake is $9.35 \mathrm{~m}$ deep, with a surface area of 4.49 ha and a maximum length of $384 \mathrm{~m}$ in the SSW-NNE direction. The bathymetric map is shown in figure 1 , whilst detailed morphometric data can be found in Toro \& Granados (2000). The substrate is mainly lake mud below 5-7 meters but sand dominates in the littoral. A large number of rocky blocks of various sizes can be found irregularly distributed all over the lake bottom. There is no macrophyte growth in the lake, except for very scarce individuals of Depranocladius exannulatus near the bottom and small areas of Fontinalis antipyretica in the littoral. It has two temporary inlets in the southern side of the lake and one outlet on the northern side, the later stream runs dry in late summer. One of the inlets is a waterfall and the other runs below the blocks of a steep snow channel. The mean annual water retention time in the lake is 62 days, but in the thaw period or during rainy autumns it could be a few days (Toro \& Granados 2000). Cimera is one of the most remote lakes in the Sierra de Gredos, and unlike other glacial lakes in this mountain range, Cimera is almost undisturbed either by tourist or cattle impact or by hydrologic regulation (Toro \& Granados 2000). The main alteration suffered in the past was the introduction of brook trout (Salvelinus fontinalis) between the 1940s and 1960s. Presently there is a stable population of this fish.

\section{MATERIALS AND METHODS}

The sampling period of the MOLAR project began in July 1996 and finished in July 1998, covering therefore two ice-covered periods and two ice-free periods. The lake was sampled monthly during ice-free period 1996 and approximately biweekly in ice-free period 1997. During ice-period 1996-1997, we could only sample the water column in spring, because of adverse meteorological conditions and the very thick ice-cover during this winter. Through the next ice-covered period (1997-1998), the late was sampled monthly. Water column profiling was performed in the deepest point of the lake. Sampling, field and laboratory methodologies were according to MOLAR project manual (Wathne \& Hansen 1997).

A $17 \mathrm{~cm}$ core (cim4/96) was taken from the deepest point of the lake by means of a Glew gravity corer in September 1996. It was extruded in the field at 3-mm 
intervals, and then transported in dark and refrigerated conditions to the laboratory for further analysis. A subsample of this core was use to determine dry weight (DW) and loss on ignition (LOI) profiles. DW was performed in a pre-weighed subsample at $105^{\circ} \mathrm{C}(24 \mathrm{~h})$ and then LOI was calculated by combustion at $550{ }^{\circ} \mathrm{C}(2 \mathrm{~h})$. Chronology was inferred by sequence slotting with the ${ }^{210} \mathrm{~Pb}$ dated master core cim1/97 (R. Thompson, pers. comm.).

For paleolimnological analysis of chironomids, a pre-weighed subsample was deflocculated in hot $\left(70^{\circ} \mathrm{C}\right)$ $\mathrm{KOH}$ for 30 minutes. Afterwards it was sieved through a $75 \mu \mathrm{m}$ mesh sieve and head capsules were sorted under $50 \times$ magnification. Small head capsules and problematic taxa were mounted in microscope slides for further observation under higher magnification. If less than 100 head capsules were recorded, another preweighed subsample was processed. Head capsules with a complete mentum were counted as one head capsule, while head capsules with a half mentum (quite common in the subfamily Orthocladinae) were counted as halves.

\section{RESULTS AND DISCUSSION}

\subsection{Ice cover}

Ice cover length is based on dates of freeze-up defined as the first date on which the lake is completely covered with ice, and dates of break-up defined as the first date on which the lake is completely ice-free (Livingstone \& Thompson, 1996). Therefore, ice cover length during the both winters studied was $c a 220$ days, ca 7 months. However, the ice free period 1996 had only been 97 days while ice free period 1997 had been 166 days, i.e. around 2 months longer. This is the result of the large accumulation of snow during winter 1996 from extremely abundant snowfalls during that year. Ice off in summer 1996 was on $5^{\text {th }}$ August, while in the two following years with a normal snow precipitation breakup was at least one month earlier (18/6/97 and 6/7/98 respectively). The thaw period in Lake Cimera is normally very long; thaw in the catchment usually starts in April when water starts to enter into the lake. In mid May 1997 and 1998, the southern part of the lake (near the outlet) was ice-free. However, ice remained in the northern littoral for one or two months more. This could be explained by the particular topography of the catchment: there is a steep north-head wall which 1) acts as snow funnel accumulating large amounts of snow over the northern ice cover, and 2) has a significant shading effect that prevents incident radiation from reaching on this part of the ice cover.

As has been found in other high mountain lakes (e.g. Catalán et al. 1990, 1992), ice cover presents a complex structure in Lake Cimera that changes throughout its duration. Maximum ice cover thickness was $>280 \mathrm{~cm}$ in the period 1996-1997 and $187 \mathrm{~cm}$ in period 1997-1998. The ice cover was composed of up to 10 layers of different thickness, granulometry and water content. In figure 2 ice cover is represented on the same scale as the lake depth. When ice cover reaches its maximum thickness, a third part of the water column can be frozen. In addition to this temporal diversity in ice cover structure, in Lake Cimera spatial diversity in ice cover structure can also be found, especially in the late part of the ice cover period. As is stated before, the southern and the northern part of the lake differ in their thickness, duration and also in the structure of their layers. Contrary to the observations made for other lakes, black ice (i.e. transparent) is not very common in Lake Cimera. In this situation where there is a thick structure of layers of slush and white ice, the transmission of the light to the water column is completely prevented.

\subsection{Water column}

Figure 2a shows water temperature in Lake Cimera throughout sampling period. There is a gap below ice cover 1996-1997 because we only have data from the last month of this period. However, it is clearly shown that an inverse thermal stratification develops during both ice cover periods. Lake Cimera has a shallow depth $(9.4 \mathrm{~m})$ that limits stratification in ice-free periods, but probably the main reason is the characteristic high winds that occurs in this mountain range. The largest difference in temperature between the surface and the lake bottom is less than $3{ }^{\circ} \mathrm{C}$, occurring just before dusk in middle summer. Maximum water temperature is related to ice break-up date: in 1996, the maximum temperature was $3.2^{\circ} \mathrm{C}$ less than the following year when ice break-up was 48 days earlier, although monthly mean air temperatures during those ice-free periods was quite close.

Figure $2 \mathrm{~b}$ shows the dissolved oxygen evolution during sampling period, again with a gap during ice cover period '96-'97. Below this ice cover there is marked oxygen depletion as a result of heterotrophic degradation of the sedimented organic matter in a situation where 1) stability of water column is very high (i.e. lowest annual values of turbulence), 2) light transmission does not occur (i.e. no primary production) and 3) gas exchange with atmosphere is prevented. In this way, the oxygen depletion has a gradient between water layers below the ice cover and water layers near the sediment. In the former case, the annual maximum dissolved oxygen values can be found associated with the lowest temperatures. In the bottom, because of an accumulation of sedimented organic matter and a small increase of temperatures, oxygen is depleted by catabolic metabolism. In this way, the ice cover formation produces changes in the aquatic environment comparable with those occurring in the hypolimnion of eutrophic lakes (Capblancq \& Laville 1978). Oxygen concentrations in the late part of the ice cover period 1996-1997 were as low as $0.1 \mathrm{mg} \mathrm{l}^{-1}$ ( $1 \%$ oxygen saturation), quite close to a completely anoxia. The intensity of this oxygen depletion in high mountain lakes is related to the 
A - Water Temperature $\left(\mathrm{T}^{\circ} \mathrm{C}\right)$

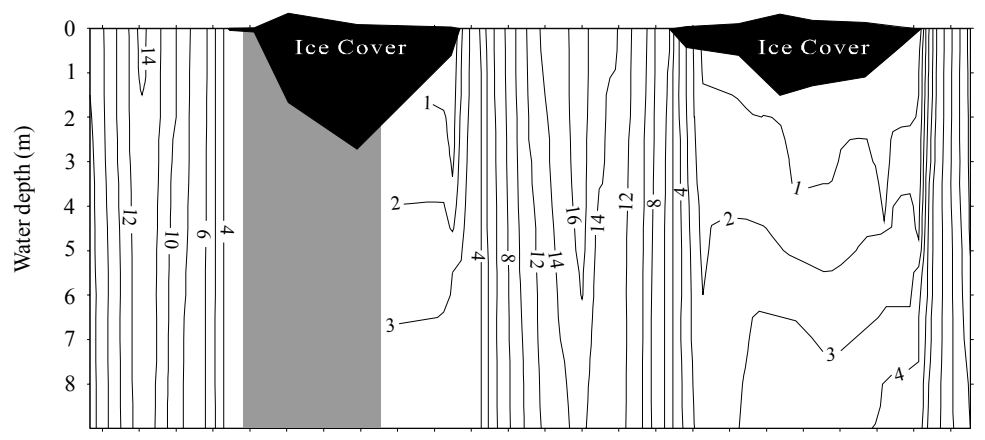

B - Dissolved Oxygen $\left(\mathrm{mg} \mathrm{O}_{2} \mathrm{l}^{-1}\right)$

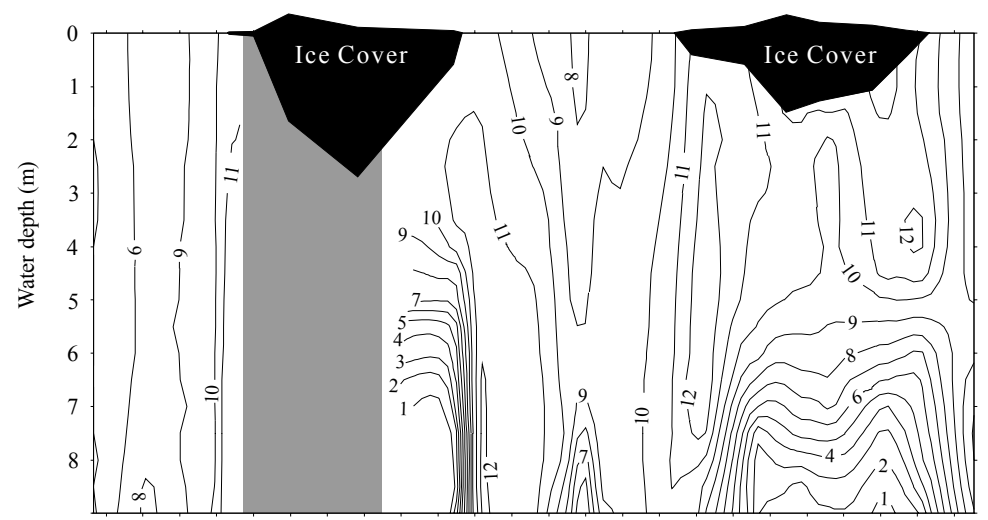

C - Chlorophyl a $\left(\mu \mathrm{g} \mathrm{l}^{-1}\right)$ and Secchi depth $(\mathrm{m})$

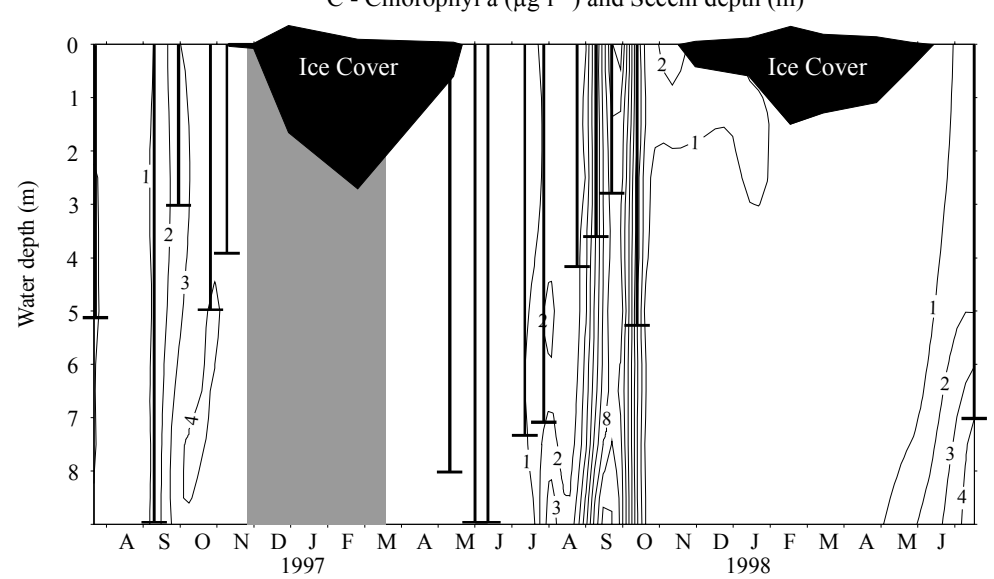

Fig. 2. Seasonal variation of water temperature (A), dissolved oxygen (B), chlorophyll- $a$ concentration and Secchi disk (C, vertical bars) in Lake Cimera. length of ice cover periods (Toro \& Granados 1997, 1998), but also to air temperatures during this period. Both ice cover periods studied had approximately the same length, but in the final stages of the first one the oxygen depletion was more severe than in the following year. This could be explained by the warm period between February and April of 1997 where lot of melting water entered the lake providing oxygen to the bottom layers. The low values of oxygen concentration changes very fast during thaw periods, and bottom oxygen depletion could rise to $100 \%$ oxygen saturation in a few days (when a lot of water flows into the lake). During the ice-free period dissolved oxygen is controlled mainly by temperature: dissolved oxygen values de- crease while water temperature increases after the thaw period, and increases while waters cools down during autumn. In middle summer, the upper layers of the water column are slightly warmer than bottom layers, and so in the formers lower oxygen concentrations can be found. However, in middle summer, especially when the outlet dries up and the water column is stable, a slight oxygen reduction can be seen in the water layers near to the bottom as a result of heterotrophic oxygen consumption again.

Figure $2 \mathrm{c}$ shows the increment of primary productivity detected by measurements of chlorophyll- $a$ concentrations in the water column. As stated above, there is no primary production below ice-cover and pigment 
concentrations rapidly fall below the detection limit. This is quite common in ice covered lakes (e.g.; Capblancq \& Laville 1978; Catalán 1992; Sherk \& Rau 1996). In both ice-free periods pigment concentrations

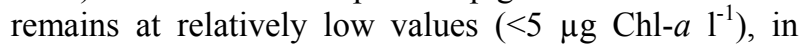
spite of the notable peak in late September 1997 as a result of a bloom of Cosmarium tinctum (de Hoyos \& Negro 2000). In figure $2 \mathrm{c}$ the Secchi depth is also shown. There is a correlation $(\mathrm{r}=0.60, \mathrm{p}<0.05)$ between Secchi depth and mean pigment concentration above this depth. However, other important factors such as solids in suspension have not been measured. Lake Cimera can be considered as an oligotrophic lake (sensu OECD, 1982) taking into account total phosphorus mean values $(6 \mu \mathrm{g}$ $\left.\mathrm{P}_{-} \mathrm{PO}_{4} \mathrm{l}^{-1}\right)$, maximum and mean annual values of chlorophyll (11.5 $\mu \mathrm{g}$ Chl- $a 1^{-1}, 2.14 \mu \mathrm{g}$ Chl- $a 1^{-1}$ respectively) and mean Secchi depth $(5 \mathrm{~m})$.

High mountain lakes are characterised by their high intrannual variability, with two marked different periods throughout the year: ice-cover vs ice-free period. The lake ecosystem differs in both periods in its productivity, its physicochemical composition, and also in its biological communities. The extent of these changes between both periods are even higher in Cimera than in other mountain lakes as a result of large differences in water temperature, oxygen content and pigment concentration between ice-covered and ice-free periods. Given that the length of the former period (and the intensity of the observed changes) is weather-related, intrannual variability (i.e. the extent of the observed changes in ecosystem structure) is also related to climatic changes. Furthermore, interannual variability is also highly dependent on the relative length of both periods, given that in the ice-free period primary production prevails over heterotrophic processes, and the inverse is the case during ice-covered period.

\subsection{Sediment record}

We have found differences in the chironomid community at different depths, but this can not be related to changes in water temperature. Some authors (Hann et al. 1992; Warner \& Hann 1987) suggest that the littoral, sublittoral and profundal components of the fossil chironomid fauna must be evaluated independently when making inferences about past temperatures, as they are differently buffered from temperature change. Although other authors (Walker et al. 1992; Walker \& Mathewes 1987) do not agree with this, in fact Lake Cimera does not have a cold hypolimnion that would prevent us using the whole chironomid community as an indicator of the past climate. Furthermore, Walker (1995) states that chironomids are excellent indicators of past climate in unstratified lakes, and Smol et al. (1991) suggest that «small or short-term climatic fluctuations will be recorded in sediments of smaller basins (like Lake Cimera) but will be damped out in larger lakes».
The relative abundance of chironomid taxa is shown in figure 3. It is based on 20 samples from the upper 17 cm of core cim4/96, expanding over $c a$ last 200 years. We have examined a total of 3857 head capsules belonging to 24 different taxa. Between 59 and 338 head capsules per g DW were found, which lies in the middle-high concentrations reported in the literature (Walker 1987). Räsänen et al. (1992) describes as extremely high values of 10-80 head capsules per g DW in a Finland lake. The most abundant taxa in Cimera were Chironomus sp. and Micropsectra spp. (M. contracta being the dominant species). Both species represent between $52 \%$ and $76 \%$ (mean $64 \%$ ) of the head capsules found in each sample. 11 species of Orthocladinae, all of them with less than $3 \%$ presence, have been summarised together. None of these species shows a defined pattern along the profile as they appear sporadically on it. Considering the entire group together, it shows a fluctuating profile with two remarkable zones: 1) the first 20 years of the $20^{\text {th }}$ century, when these Orthocladinae species were very scarce, and 2) the upper half centimetre (1994-1997), where these species disappear. There are two Orthocladinae species that have appreciable numbers at least in some layers: Heterotrissocladius marcidus and Synorthocladius semivirens. The former has a nearly constant value below $10 \%$, although its presence decreases in the first 1 or $2 \mathrm{~cm}$. Inversely, $S$. semivierens shows a slight increase during the $20^{\text {th }}$ century with its maximum in recent years. Diamesa species has grater values around second half of the $19^{\text {th }}$ century and in recent years reaches its minimum values. The other Diamesinae, Pseudodiamesa sp., and the Prodiamesinae Prodiamesa olivacea have very scarce representatives in all samples analysed. In fact, $P$. olivacea only appears in the bottom of the core. The Tanypodinae show a more interesting profile. While Procladius + Macropelopia head capsules remains approximately constant throughout the profile, Ablabesmyia longistila has a notable increase in the upper $2 \mathrm{~cm}$ (i.e. in the last 15-20 years). The Chironominae also show important changes. Chironomus sp., the second most abundant species, has a fluctuating profile with relatively low values in the surface sediment layers. Micropsectra spp. (mainly M. contracta) is the most abundant taxa of fossil chironomids. Inversely to Chironomus, this genus seems to increase in the top layers of the core, although it is not a clear trend. Cladotanytarsus sp. also show a changing profile along the core, but the start of this change is below the level of the changes mentioned for the other species. Cladotanytarsus fluctuates from very low values in the $19^{\text {th }}$ century to high values throughout the $20^{\text {th }}$ century. Finally, the other Chironominae (Paracladopelma camptolabis, Tanytarsus + Virgatanytarsus sp., and the unidentificable Tanitarsinii) do not show significant changes during the last 200 years.

Based on the results of cluster analysis, two main stratigraphic zones have been recognised in the core A 


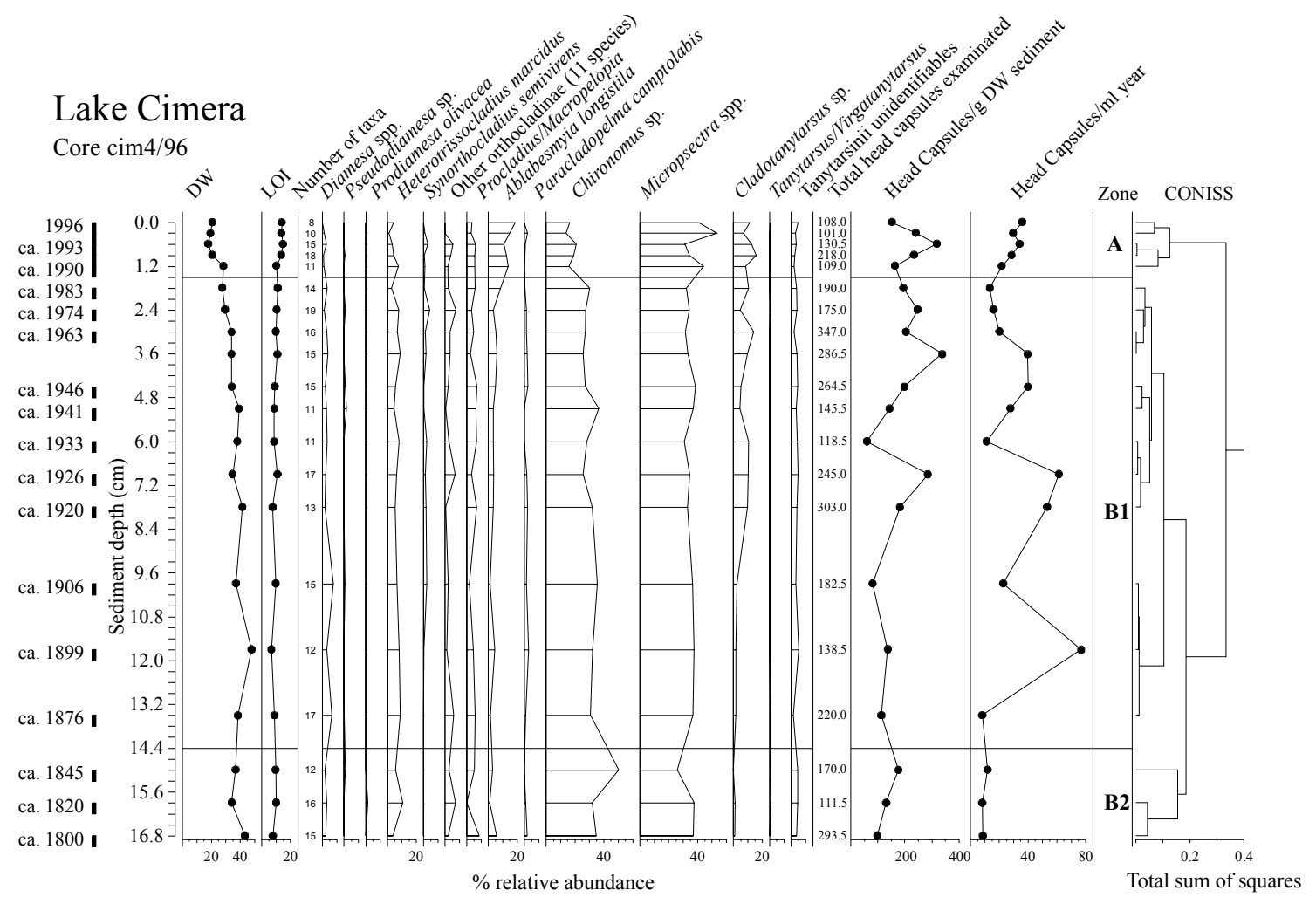

Fig. 3. Stratigraphical diagram showing relative abundance (percentage) of Chironomidae head capsules in core Cim4/96.

and $\mathrm{B}$, the latter has been subdivied in two sub-zones (B1 and B2).

Zone A comprises the top $1.5 \mathrm{~cm}$ corresponding to the 1990s. This zone is mainly characterised by the low relative abundance of Chironomus and $H$. marcidus, while there is an increase of Ablabesmia longistila and Micropsectra sp. It has lower taxonomic richness than the two other zones. It also shows an increasing influx of head capsules into the sediment per year.

Zone B1 has the greatest depth (and also the longest time period) from $1.5 \mathrm{~cm}$ to $\mathrm{ca} 14.4 \mathrm{~cm}$, expanding from middle 19 th century to the last 1980 s of the $20^{\text {th }}$ century. In this zone the species composition remains approximately constant. Nevertheless, in the upper part of this zone there is a marked increase of Cladotanytarsus sp., while the bottom part is especially rich in Diamesa spp. and relatively poor in Orthocladinae taxa. The influx of head capsules into the sediment fluctuates throughout this zone.

Zone B2 is recognised by its maximum of Chironomus sp. and minimum of Micropsectra spp. abundance. It has a very low influx of head capsules per year into the sediment.

\subsubsection{Ecological interpretation and temperature reconstruction}

The date of introduction of the brook trout (Salvelinus fontinalis) to Lake Cimera is not know precisely, but it must be between the 1940s and 1960s. There is a wide literature concerning benthos community changes as a response to fish introduction (e.g. Goyke \& Hershey 1992; Johnson et al. 1996). In fact, based on our analysis of fish stomach's content we know that Chironomus pupae could be the main trophic resource of this species in Lake Cimera at least during emergency periods. Writers such as Hofer \& Medgyesy (1997) suggest that chironomids could compose as much as $80 \%$ of the diet in winter and provide a significant resource during emergence periods in another high mountain lake. Nevertheless, the fish stocking occurred at least 30 years earlier than the main observed change in the chironomid community. Therefore, we must discard this introduction as the main explanation for the observed changes in the fossil assemblage.

As far as we know, Lake Cimera has suffered no other important impacts in its catchment (tourist impact, cattle, wastewater, hydrologic regulation) like other lakes in this mountain range (Toro et al. 1993; Toro \& Granados 2000). Furthermore, in the AL:PE2 project acidification in Lake Cimera was not detected (Wathne \& Johannessen 1995; Camarero et al. 1995). Rieradevall et al. (1998) did not find acidification affecting zoobenthos of remote Iberian mountain lakes. However, Thompson \& Agusti (pers. comm.) have found an important air temperature warming in Lake Cimera starting in the middle 1980s. As this climate change is quite close to the main change observed in fossil chironomids assemblage, we hypothesise that this recent climate 
warming could be the main factor driving the changes in the chironomid community.

There are two main consequences of a warmer year: the ice cover length is shorter and the maximum water temperature during ice-free period usually is higher. If we look at the chironomid species that appear in the core, the presence of Chironomus sp. is noticeable because it is not a common genus in high mountain lakes (Walker 1993). Within the 28 AL:PE and MOLAR lakes, Chironomus spp. have been found only in two lakes: Cimera and Lille Hovatn (Norway; Schnell 1998). Nevertheless, the latter is relatively depth (22 m), located just below the tree line (Wathne et al. 1995) and it is chronically acidified (Schnell \& Willansen 1996). So from this point of view it is less comparable with the other arctic/alpine lakes. Chironomus species are usually found in aquatic ecosystems with moderate or high concentrations of organic matter and/or nutrients (Johnson et al. 1990; Walker 1993; Prat 1993; Meriläinen \& Hamina 1993; Brodersen \& Lindegaard 1997), features that are not common in pristine high mountain lakes. Lake Cimera is an oligotrophic lake according to the OECD (1982) nutrient, pigment and transparency values. However, given that it has severe oxygen depletion during the ice-cover period, Chironomus sp. is favoured by its adaptation to this low dissolved oxygen concentration. Capblancq \& Laville (1983) also found Chironomus in a high mountain lake in the Pyrennes with high oxygen depletion during the period of winter ice cover. They reported the replacement of the typical oligotrophic fauna with more a eurythermal and euroxibiont fauna Other chironomid species better adapted to rich oxygen cold environments are more abundant than Chironomus where oxygen depletion is not as severe as in Lake Cimera, as occurs in other MOLAR lakes (Schnell 1998) and other lakes in the same mountain range (Toro \& Granados 1997). Since warmer years are known to have shorter ice-cover periods and/or an earlier thaw in the catchment, the lower level of oxygen depletion in bottom layers, would not be expected to favour Chironomus presence. Ice cover length has been seen to affect the presence of estenobiontic chironomidae through controlling profundal oxygen deficit (Walker 1987; Hofmann 1988). As stated by Thompson \& Agusti (per. comm.), mean air temperature for 1990 s has been $1.4{ }^{\circ} \mathrm{C}$ above the mean temperature of previous years. Throughout this decade, Chironomus has fallen to its minimum relative abundance. Several authors (e.g., Wiederholm \& Eriksson 1979; Schakau 1990; Räsänen et al. 1992; Meriläinen \& Hamina 1993; Salonen et al. 1993; Walker 1995; Simola et al. 1996) have interpreted the increase of Chironomus species as an enrichment/eutrophication phase. However, no trophic changes have been observed during recent years in Lake Cimera, as revealed by analysis of fossil pigments and nutrients deposition (Lami 2000, this issue).
As hypothesised here, Chironomus relative abundance in Lake Cimera must be related to climate variability through the length of the ice-cover period and the intensity of the changes in the lake ecosystem associated with this period. Figure 4 shows the linear regression between Chironomus relative abundance and reconstructed air temperature performed by Thompson \& Agusti (pers. comm.). Because each layer of the core analysed for chironomid head capsules comprises different time intervals, the climate reconstruction has been recalculated as the mean temperatures of the years comprising each analysed layer for chironomids. As is shown, Chironomus is significantly correlated with reconstructed air temperatures $(n=20, r=-0.75$, $\mathrm{p}<0.001)$. This means that as is hypothesised above, Chironomus relative abundance tends to be lower during warmer periods. However, the oxygen depletion in Lake Cimera can not be extremely severe because in such cases the sediment record has either no head capsules or a very low concentration of head capsules (e.g. Wiederholm \& Eriksson 1979).

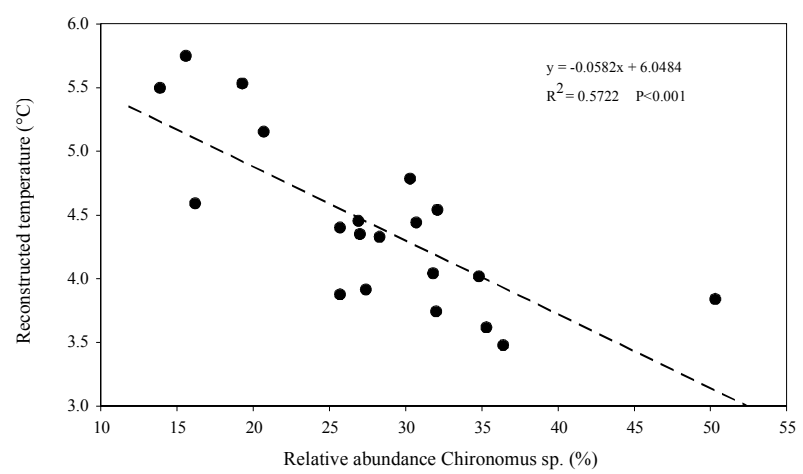

Fig. 4. Relationship between the relative abundance of Chironomus sp. in 20 analysed layer of core cim4/96 and reconstructed air temperatures for the years comprising each layer. Air temperature data has been modified (see text) from Thompson \& Agusti (pers. comm.).

Interpretations based upon single indicator species are often considered to be unreliable. Nevertheless, it was observed that other taxa do not falsify our hypothesis of a recent warming. Cold stenotherm species like $H$. marcidus (Walker 1993; Saether 1975) and Diamesa spp. (Rossaro 1991) also slightly decrease in abundance, because mean water temperature also tends to increase in these warmer years. Other species such as Micropsectra sp. and A. longistyla, which are not particularly cold stenotherm, increase in percentage abundance. Changes in Heterotrissocladius and Chironomus abundance have been related also to changes in sedimentary rates and/or in organic content (Warwick 1980, 1989). Although Appleby (2000, this issue) had found some changes in the sedimentary rate, they do not correspond with the observed change in the relative abundance of these species. Figure $3 \mathrm{~b}$ also shows dry weight (DW) and loss on ignition (LOI) profiles. DW increases 
slightly towards the bottom of the core whilst LOI decreases slightly. The only significant change is in the uppermost sediment (corresponding to 1990s) where DW has a greater decrease and LOI reaches its maximum values. It is not clear if these changes indicate a higher influx of organic matter to the sediment, but they may reflect 1) that the upper millimetres are still unconsolidated by the weight of the sediments layers above them, and 2) that all easily metabolised organic matter has not yet been degraded.
This transfer function was developed to infer mean summer (June, July, August) air temperature. As a result of different taxonomic resolution between the modern training set and the fossil assemblages, the taxonomy of the fossil assemblages was harmonised with that of modern training set: 6 taxa identified to species level in the fossil assemblage were treated at genus level (e.g. Heterotrissocladius marcidus as Heterotrissocladius sp.); 10 taxa were at the same taxonomic level in both data sets (so no changes were made); 8 taxa were treated
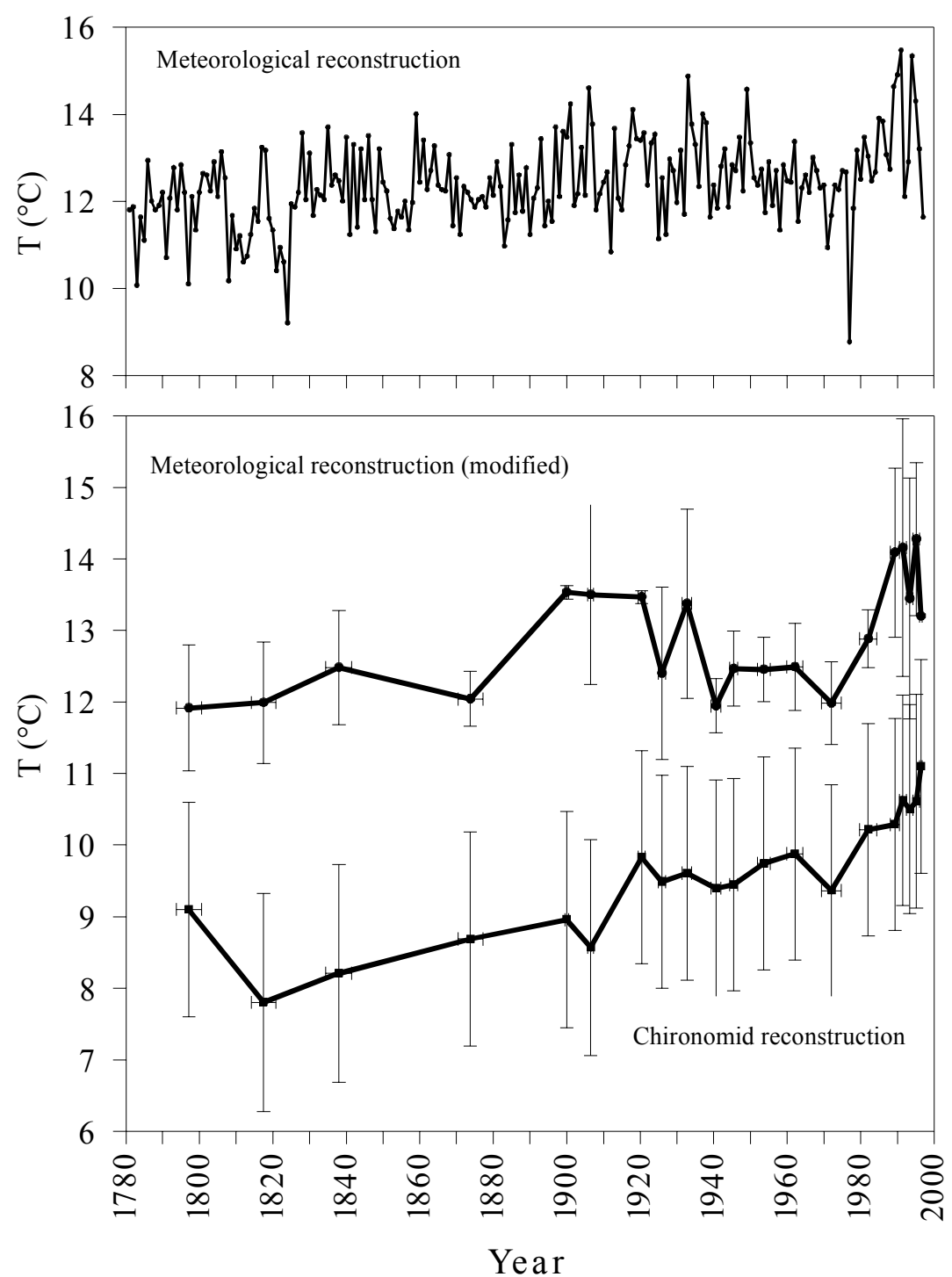

Fig. 5. Upper graph: Reconstructed mean summer air temperatures (annual data; Thompson \& Agusti, pers. comm.). Lower graph: Reconstructed mean summer air temperatures in Lake Cimera by means of climate model and chironomid calibration model (Lotter, pers. comm.); The former reconstruction has been modified using mean values of the years comprising each analysed layer for chironomid head capsules (see text for details).
Chironomids have been used by some authors to develop models for reconstructing temperatures (Walker et al. 1991; Lotter et al. 1997; Olander et al. 1997) although there is no modern training set of chironomids for the Iberian Peninsula. However, we have used the model developed by Lotter et al. (1997) for the Alps because this is the nearest geographical region with a training set and the chironomid fauna used in this calibration set is quite similar to that found in central Spain. as Orthocladinae indet. all together, because neither the species nor the genus were present in the modern training set. These last 8 taxa have a mean abundance of $1 \%$ or less throughout the core.

Figure 5 shows mean summer temperature inferred by means of fossil chironomid assemblages (Lotter, pers. com.) and also the reconstructed temperatures using long climate series (Thompson \& Agusti, pers. comm.). Again, the climate reconstruction has been 
recalculated as the mean summer temperatures of the years comprising each layer analysed for chironomids. In this way, both curves are comparable as each point represents a similar time scale.

Comparing both summer reconstructions, it appears that Chironomid reconstruction underestimates by $\mathrm{ca} 3$ ${ }^{\circ} \mathrm{C}$ reconstruction based on climate series. This is probably because the model has been developed for a different geographical region. Some authors have hesitated to use calibration models outside their geographical region (e.g. Brooks 1996). However, as the chironomid fauna used in the calibration set is quite similar to those that found in central Spain, we expected the reconstruction to show the general trends in temperature although absolute values are not reliable. Considering this, both reconstruction shows the same tendency. A general trend of recent warming is detected by both models. The linear regression of these models gives a slope of 0.00668 ${ }^{\circ} \mathrm{C}^{-1}$ (meteorological model, $\mathrm{n}=20, \mathrm{p}<0.05$ ) and $0.00496{ }^{\circ} \mathrm{C} \mathrm{y}^{-1}$ (chironomid model, $\mathrm{n}=20, \mathrm{p}<0.05$ ). The slopes are significantly different $(\mathrm{df}=36 ; \mathrm{t}=$ $15.95 ; \mathrm{p}<0.001$ ) the difference between both slopes being 0.0015 to $0.0019^{\circ} \mathrm{C}^{-1}$ with a $95 \%$ confidence interval. However, as is discussed before in the ecological interpretation of fossil chironomids, recent warming seems not to be a linear trend, but there is a major change $\mathrm{ca}$ middle 1980s. In fact, before mid 1980s the meteorological model does not show a significant linear trend $(\mathrm{n}=15, \mathrm{p}=0.37)$ although chironomid inferred temperatures still show a linear trend of progressive warming $(\mathrm{n}=15, \mathrm{p}<0.05)$.

Taking this into consideration, it is important to verify whether or not both models reflect the same changes in mean summer temperatures during the period of study. Both reconstructions are significantly correlated ( $\mathrm{n}=20, \mathrm{r}=0.45, \mathrm{p}<0.01)$. Furthermore, climate reconstruction shows 4 «cooling» events near 1993, 1974, 1941 and 1926; these events are also easily recognised in the chironomid reconstruction, although chironomids seem not to reflect the full amplitude of these episodes. Before 1925, both curves do not match as well. In fact, if we consider only the data after this date the correlation is clearly higher $(\mathrm{n}=13, \mathrm{r}=0.75, \mathrm{p}<0.01)$. Two reasons can be given to explain the fact that models fit better in recent years: 1) Fewer samples are analysed in the bottom of the core so it is difficult to find detailed trends, and 2) dating of bottom layers presents more uncertainties than in surface layers (Appleby 2000, this issue). For instance, close to 1820 temperatures inferred by means of fossil chironomids have minimum values throughout the core, while climate reconstruction for these years do not show this relatively cool event. But it is noticeable that it is precisely these years that have a warmer peak between two colder periods. The ${ }^{210} \mathrm{~Pb}$ dating for 1847 has a mean error of \pm 16 years (Appleby 2000 , this issue), and before this year dates has been extrapolated assuming the same sedimentation rate. There- fore, the lowest values inferred by chironomid head capsules near 1820 could in fact reflect the colder period before or after the 1817 warm peak.

The maximum temperature difference in the climate reconstruction for the last 200 years is $2.4{ }^{\circ} \mathrm{C}$ while for the chironomid reconstruction it is $3.3{ }^{\circ} \mathrm{C}$. Taking into account only the period where the models fit better (i.e. after 1925) the maximum temperature differences are 2.4 and $1.7{ }^{\circ} \mathrm{C}$ respectively. In summary, we have two different and independent models that reflect a clear climate warming in the mountains of Central Spain during the last years. There is an uncertainty about the extent of this warming but it is likely to be greater than $1.5^{\circ} \mathrm{C}$. The significant correlation between both models, at least in the upper sediments, also confirms the viability of using fossil chironomids as a tool to reconstruct paleotemperatures.

\section{CONCLUSIONS}

Climate variability in this kind of relatively shallow high mountain lake is a key factor in determining maximum summer water temperature and winter oxygen depletion, through controlling ice cover length and the start of the thaw period. These climate driven changes in ecosystem structure, which are relatively large in magnitude for Lake Cimera, are also significantly correlated with the relative abundance of low oxygen adapted species like Chironomus sp. Independent models developed to reconstruct air temperatures in Lake Cimera, one based on long climate series (Thompson \& Agusti, pers. comm.) and the other based on transfer functions of chironomids fossil assemblages (Lotter, pers. comm.) correlate significantly. Both models, and the ecological interpretation of Chironomus relative abundance, reflect a recent warming in Lake Cimera. The extent of this warming is not clearly known, but it is likely to be an increase of at least $1.5^{\circ} \mathrm{C}$ in mean summer air temperatures since mid 1980s.

\section{ACKNOWLEDGMENTS}

Sampling work would not have been possible without the help of many colleagues from the Ecology Department of the Universidad Autónoma de Madrid and other ecologists and mountaineers. Special thanks are due to Santiago Robles and Jose Miguel Rodriguez for their effort in our work in mountain lakes in the Sistema Central. Susana Escribano, Nieves Lopez, Yolanda Díaz \& Mariluz de Pablos provided laboratory assistance. We would like to thank also our colleagues in MOLAR project for useful discussion and hospitality during our scientific meetings. We are particularly grateful to André Lotter for reconstructing Cimera temperature with the calibration model developed with chironomids in the Alps and his useful discussion. We want to thank as well the Junta de Castilla y León that provides authorisation for sampling Lake Cimera and for the facilities transporting material with helicopter. MOLAR project was funded by EU (contract ENV4-CT95-0007). 


\section{REFERENCES}

Appleby, P.G. 2000. Radiometric dating of sediment records in European mountain lakes. In: A. Lami, N. Cameron \& A. Korhola (Eds), Paleolimnology and ecosystem dynamics at remote European Alpine lakes. J. Limnol., 59 (Suppl. 1): 1-14.

Brodersen, K.P. \& C. Lindegaard. 1997. Significance of subfossile chironomid remains in classification of shallow lakes. Hydrobiologia, 342: 125-132.

Brooks, S.J. 1996. Three thousand years of environmental history in a Cairngorms Locham revealed by analysis on non-biting midges (Insecta:Diptera:Chironomidae). Bot. $J$. Scotl., 48(1): 89-98.

Capblancq, J. \& H. Laville. 1983: Le Lac de Port-Bielh (Pyrénées): exemple de fonctionnement d'un écosystéme lacustre de haute montagne. In: M. Lamotte \& F. Bourlre (Eds), Problèmes d'Ecologie: Structure et fonctionnement des écosystèmes limniques. Masson, Paris: 51-80 pp.

Camarero, Ll., J. Catalán, S. Pla, M. Rieradevall, M. Jiménez, N. Prat, A. Rodriguez, L. Encina, L. Cruz-Pizarro, P. Sanchez Castillo, P. Carrillo, M. Toro, J. Grimalt, L. Berdie, P. Fernandez \& R. Vilanova. 1995. Remote mountain lakes as indicators of diffuse acidic and organic pollution in the Iberian Peninsula (AL:PE 2 Estudies). Water, Air and Soil Pollution, 85: 487-492.

Catalán, J. 1992. Evolution of dissolved and particulate matter during the ice-covered period in a deep, high-mountain lake. Can. J. Fish. aquat. Sci., 49: 945-955.

Catalán, J., E. Ballesteros, Ll. Camarero \& E. Garcia. 1990. Aspectos generales de la limnología invernal de dos lagos pirenaicos morfológicamente muy distintos (estany Redó y estany Baciver). Scientia Gerundensis, 16/2: 55-68.

Catalán, J., E. Ballesteros, Ll. Camarero, M. Felip \& E. Gacia 1992. Limnology in the Pyrenean lakes. Limnetica, 8: $27-$ 38.

Goyke, A.P. \& A.E. Hershey. 1992. Effects of fish predation on larval chironomid (Diptera: Chironomidae) communities in an artic ecosystem. Hydrobiologia, 240: 203-211.

Hann, B.J., B.G. Warner \& W.F. Warwick. 1992. Aquatic invertebrates and climate change: a comment on Walker et al. (1991). Can. J. Fish. aquat. Sci., 49: 1274-1276.

Hofer, R. \& N. Medgyesy. 1997. Growth, reproduction and feeding of dwarf Arctic char, Salvelinus alpinus, from an Alpine high mountain lake. Arch. Hydrobiol., 138: 509524.

Hofmann, W. 1988. The significance of chironomid analysis (Insecta: Diptera) for paleolimnological research. Palaeogeogr. Palaeoclimatol. Palaeoecol., 62: 501-509.

Hoyos (de), C. \& A. Negro. 2000. El fitoplancton de las lagunas de Gredos. In: M. Toro \& I. Granados (Ed), Las lagunas de la Sierra de Gredos. Monografías de la Red de Espacios Naturales de Castilla y León. Ed. Junta de Castilla y León. Valladolid.

Johnson, M.G., J.R.M. Kelso, O.C. Mcneill \& W.B. Morton. 1990. Fossil midge associations and the historical status of fish in acidified lakes. J. Palaeolimnol., 3: 113-127.

Johnson, D.M., T.H. Martin, P.H. Crowley \& L.B. Crowder. 1996. Link strength in lake littoral food webs: Net effects of small sunfish and larval dragonflies. J. N. Am. Benthol. Soc., 15: 271-288.

Lami, A., P. Guilizzoni \& A. Marchetto. 2000. High resolution analysis of fossil pigments, carbon, nitrogen and sulphur in the sediment of eight European alpine lakes: the MOLAR project. In: A. Lami, N. Cameron \& A. Korhola (Eds), Paleolimnology and ecosystem dynamics at remote European Alpine lakes. J. Limnol., 59 (Suppl. 1): $15-28$

Livingstone D. \& R. Thompson, 1996. Climatology and Meteorology. In: B.M. Wathne (Ed.), MOLAR. Project Manual. NIVA-Report $\mathrm{n}^{\mathrm{o}} \mathrm{O}-96061$.
Lotter, A.F., H.J.B. Birks, W. Hofmann \& A. Marchetto. 1997. Modern diatom, cladocera, chironomid, and chrysophyte cyst assemblages as quantitative indicators for the reconstruction of past environmental conditions in the Alps .1. Climate. J. Palaeolimnol., 18: 395-420.

McDonald, M.E., A.E. Hershey \& M.C. Miller. 1996. Global warming impacts on lake trout in artic lakes. Limnol.Oceanogr., 41(5): 1102-1108.

Meriläinen, J.J. \& V. Hamina. 1993. Recent environmental history of a large, originally oligotrophic lake in Finland: a palaeolimnological study of chironomid remains. $\mathrm{J}$. $\mathrm{Pa}$ laeolimnol., 9: 129-140.

OECD. 1982. Eutrophication of Water, Monitoring, Assesment and control. Paris: $150 \mathrm{pp}$.

Olander, H., A. Korhola \& T. Blom. 1997. Surface Sediment Chironomidae (Insecta: Diptera) Distribution along an Ecotonal Transect in Subartic Fennoscandia: Developing a Tool for Palaeotemperature Reconstructions. J. Palaeolimnol., 18: 45-59.

Prat, N. 1993. El zoobentos de los lagos y embalses españoles. Actas VI Congreso Español de Limnologia: 11-22.

Räsänen, M., J. Salonen, J. Salo, M. Walls \& J. Sarvala. 1992. Recent history of sedimentation and biotic communities in Lake Pyhajarvi, SW Finland. J. Palaeolimnol., 7: 107-126.

Rieradevall, M., M. Jiménez \& N. Prat. 1998. The zoobenthos of six remote high mountain lakes in Spain and Portugal. Verh. int. Ver. Limnol., 26: 2132-3136.

Rossaro, B. 1991. Chironomids and water temperature. Aquat. Ins., 13: 87-98.

Saether, O.A. 1975. Neartic and paleartic Heterotrissocladius (Diptera: chironomidae). Bull. Fish. Res. Board Can., 193: $1-67$.

Salonen, V.P.P., A. Alhonen, A. Itkonen \& H. Olander. 1993. The trophic history of enajarvi, SW Finland, with special reference to its restoration problems. Hydrobiologia, 268: 147-162.

Schakau, B. 1990. Stratigraphy of the fossil Chironomidae (Diptera) from Lake Grasmere, South Island, New Zeland, during the last 6000 years. Hydrobiologia, 214: 213-221.

Schnell, O. 1998. Guidelines for the Identification of Chironomid Larvae in the MOLAR Project. NIVA Report SNO 3710-97.

Schnell, O.A. \& E. Willansen. 1996. The chironomid (Diptera) communities in two sediment cores from Store Hovvatn, S.Norway, an acidified lake. Annls. limnol., 32(1): 45-61.

Sherk, T. \& G. Rau. 1996. Emergence of Chironomidae from Findley Lake in the coniferous forest of the Cascade Mountains after early and late thaws. Hydrobiologia, 318 85-101.

Smol, J.P., I. Walker \& P.R. Leavitt. 1991. Paleolimnology and hindcasting climatic trends. Verh. int. Ver. Limnol., 24: $1240-1246$.

Simola, H., J.j. Merilainen, O. Sandman, V. Marttila, H. Karjalainen, M. Kukkonen, R. Julkunentiitto \& J. Hakulinen. 1996. Palaeolimnological analyses as information source for large lake biomonitoring. Hydrobiologia, 322: $283-$ 292.

Toro, M., R.J. Flower, N. Rose \& A.C. Stevenson. 1993. The sedementary record of the recent history in a high mountain lake in central Spain. Verh. int. Ver. Limnol., 25: 1108-1112.

Toro, M. \& I. Granados. 1997. Laguna de Peñalara. Seguimiento Limnológico y Control de las Medidas Adoptadas en la Gestión del Parque Natural (Julio1995-Diciembre1996). Informe para la A.M.A. de la Comunidad de Madrid: $130 \mathrm{pp}$

Toro, M. \& I. Granados. 1998. Laguna de Peñalara. Seguimiento Limnológico y Control de las Medidas Adoptadas en la Gestión del Parque Natural (Año 1997). Tomo I: Evolución fisico-química del medio. Tomo II: Efecto del 
Salvelino sobre la comunidad acuática. Informe para la A.M.A. de la Comunidad de Madrid.

Toro M. \& I. Granados (Eds). 2000. Las lagunas de la Sierra de Gredos. Monografías de la Red de Espacios Naturales de Castilla y León. Ed. Junta de Castilla y León. Valladolid.

Walker, I. 1987. Chironomidae (Diptera) in palaeoecology. Ouaternary Science Reviews, 6: 29-40.

Walker, I. 1993. Paleolimnological biomonitoring using freshwater benthic macroinvertebrates; In: D.M. Rossenberg \& V.H. Resh (Eds), Freshwater Biomonitoring and Benthic Macroinvertebrates. Chapman \& Hall, Inc.: 306343.

Walker, I. 1995. Chironomids as indicators of past environmental change. In: P.D. Armitage, P.S. Craston \& L.C. Pinder (Eds), The chironomidae: Biology and ecology of non-biting midges. Chapman \& Hall: 405-422.

Walker, I. \& R.W. Mathewes. 1987. Chironomids, lake trophic status and climate. Quaternary Research, 28: 431437.

Walker, I. \& R.W. Mathewes. 1989. Much ado about dead diptera. J. Palaeolimnol., 2: 19-22.

Walker, I., J.P. Smol \& H.J.B. Birks. 1992. Aquatic invertebrates, climate scale and statistical hypothesis testing: a response to Hann, warner, and Warwick. Can. J. Fish. aquat. Sci., 49: 1276-1279.

Walker, I., J.P. Smol, D.R. Engstrom \& H.J.B. Birks. 1991. An assessment of chironomidae as quantitative indicators of past climatic change. Can. J. Fish. aquat. Sci., 48: 975987.

Warner, B.G. \& B.J. Hann. 1987. Aquatic invertebrates as paleolimnological indicators? Quaternary Research, 28: 427-430.

Warwick, W.F. 1980. Chironomidae (Diptera): response to 2800 years of cultural influence: a paleoecological study with special reference to sedimentation, eutrophication and contamination processes. Can. Ent., 112: 1193-1238.

Warwick, W.F. 1989. Chironomids, lake development and climate: a comentary. J. Palaeolimnol., 2: 15-17.

Wathne, B.M. \& H.H. Hansen. 1997. MOLAR. Measuring and modelling the dynamic response of remote mountain lake ecosystem to environmental change: A program of Mountain lake Research. MOLAR Project Manual. NIVA Report 0-96061, Oslo.

Wathne, B.M. \& M. Johannessen. 1995. AL:PE2 Report (January 1994-January 1995). European Comission Report.

Wathne, B.M., S.T. Patrick, D. Monteith \& H. Barth (Eds). 1995. AL:PE1 Report (period April 1991-April 1993). Ecosystems Research Report 9. European Commission Report EUR 16129 EN.

Wiederholm, T. \& L. Eriksson. 1979. Subfossil chironomids as evidence of eutrophication in Elkon Bay, central Sweden. Hydrobiologia, 62: 195-208. 